Елена Зубкова

\title{
“СОВЕТСКИЙ НИЩИЙ»: ОПЫТ РЕКОНСТРУКЦИИ КОЛЛЕКТИВНОГО ПОРТРЕТА 1950-Х ГГ.
}

Статья рассматривает реконструкцию коллективного портрета советских нищих середины 1950-х гг.- комплекс социально-демографических, экономических, социокультурных характеристик, дающих представление о нищих как маргинальной социальной группе. Исследование основано на материалах статистического учета нищих Министерства внутренних дел СССР и документах Комитета государственного контроля СССР, который в 1954 г. организовал масштабную проверку состояния борьбы с нищенством в городах и регионах страны. Источники содержат информацию о численности, возрасте, уровне материального обеспечения, состоянии здоровья, мотивации людей, занимающихся нищенством. Обобщенные характеристики дополняют отдельные жизненные истории нищих. Факторы риска, толкающие людей на путь нищенства, были самыми разными: бедность, отсутствие социальной поддержки, преклонный возраст, инвалидность, болезнь (в том числе алкогольная зависимость), отсутствие жилья (бездомность), сиротство, многодетность, невозможность найти работу, одиночество, наличие судимости, утрата документов. Как правило, к нищенству вела их совокупность. Среди людей, занимающихся нищенством, можно выделить несколько социальных типажей: инвалиды, старики, одинокие матери с детьми, многодетные родители, люди с судимостью, выпускники детских домов, бывшая домашняя прислуга, лица, страдающие алкогольной зависимостью. Эти типажи, как и факторы риска, часто носили смешанный характер. Типичная фигура нищего - одинокий пожилой инвалид. Свою нишу занимали «профессиональные» нищие, хотя по численности они уступали «вынужденным» нищим. Советские нищие в основном рекрутировались из социально уязвимых слоев населения. Наличие значительного числа людей, для которых нищенство стало основной стратегией выживания, а также широкого спектра факторов риска, провоцирующих

Елена Юрьевна Зубкова - д. и. н., главный научный сотрудник, руководитель Центра социальной истории России, Институт российской истории РАН, Москва, Россия. Электронная почта: elena.zubkova@mail.ru 
нищенство, свидетельствовало о серьезных изьянах советской социальной политики, особенно в части поддержки незащищенных слоев населения и разработки адаптационных стратегий для аутсайдеров.

Ключевые слова: нищенство, бедность, социальная политика, эксклюзия, маргинальность

DOI: $10.17323 / 727-0634-2018-16-2-221-236$

Словосочетание «советский нищий» звучит довольно непривычно. Однако среди представителей социального андеграунда нищий - фигура универсальная: нищенство не знает не только государственных границ, но и ее хронологические границы достаточно широки, чтобы внести этот вид занятости в реестр древнейших профессий. С точки зрения функционального подхода, нищенство (попрошайничество) можно разделить на два способа жизнеобеспечения (за счет подаяний, милостыни) - вынужденный, обусловленный крайней бедностью, и профессиональный, с реальным уровнем жизни, как правило, не связанный (Бутовская и др. 2007: 11; Ильясов, Плотникова 1994: 150). Соответственно, причины, побуждающие к попрошайничеству, исследователи делят на «истинные» и «ложные», которые испытывают те, кто нуждается в социальной помощи, или профессионалы-мошенники.

Культура нищенства несет на себе печать давней традиции, тем не менее она подвижна, отличается национальной, географической, исторической спецификой (Althammer 2007). Так, о нищенстве в СССР ведется особый разговор. Исследователи современного нищенства в России отмечают историко-культурную преемственность в стратегиях попрошайничества «новых нищих», воспроизводящих дореволюционные практики (Дьяконов 2007). Советский период в данном сравнительном контексте, за редким исключением, не рассматривался. Вместе с тем нищенство как явление существовало в СССР, хотя даже на своем «пике» в 1920-е гг. не достигало таких масштабов, как до революции: Всероссийская перепись населения 1897 г. зафиксировала цифру в 362514 человек, а по данным переписи 1926 г.- в РСФСР нищих насчитывалось 133 118, вместе с Украиной и Белоруссией - 162815 (Левенстим 2004: 19; Герцензон 1995: 69). Социальные и политические потрясения XX в., войны и экономические кризисы культивировали маргинальность в советском обществе, превращая граждан в изгоев. Низкий уровень жизни, отсутствие социальной поддержки становились фактором риска для людей, живущих за чертой бедности. Маргинальность и бедность провоцировали нищенство, а нищий становился привычной фигурой советской повседневности (Zubkova 2013).

Что представлял собой феномен нищенства в СССР, каковы причины и мотивы, толкающие людей на путь попрошайничества, какие меры социальной защиты и профилактики нищенства могло предложить государство 
и общество? Наконец, кто он - «советский нищий», какие группы населения формировали социальное лицо нищенства? Статья выстроена по принципу «моментальной фотографии»: это коллективный портрет советского нищего, зафиксированный на одном хронологическом отрезке - в середине 1950-х гг., до пенсионной реформы 1956 г. Десять лет отделяют этот хронологический рубеж от окончания войны, катастрофические последствия которой дали новый всплеск нищенства в стране. Пенсионная реформа 1956 г. стала одной из основных составляющих новой социальной политики, направленной на преодоление бедности и на профилактику нищенства.

Закрытые сообщества - сложный объект для изучения. В отношении советских маргинальных групп эта задача сложна вдвойне. Основную массу доступных для историка документов советского времени (за исключением периода 1920-х гг.) составляют материалы правоохранительных органов и социальных служб, т. е. структур, представляющих государство. Для них нищие, бродяги, проститутки, уголовники - объекты государственной политики контроля. Взгляд с позиции субъекта в документах государственных институтов почти не присутствует; он обозначен, но в виде исключения - например, в милицейских протоколах или опросных листах при задержаниях. По документам можно изучать государственную политику по отношению к социальным маргиналам, но возможности реконструкции картины мира представителей советского андеграунда, в том числе нищих, на основе этих источников носят весьма ограниченный характер.

Вместе с тем имеющийся в нашем распоряжении информационный ресурс позволяет - не в режиме плотного описания, но в эскизах - выстроить коллективный портрет советского нищего 1950-х гг. Это не коллективная биография, а комплекс социально-демографических, экономических, социокультурных характеристик, дающих представление о нищих как маргинальной социальной группе: численность, возраст, уровень материального обеспечения, состояние здоровья, мотивация людей, занимающихся нищенством. Объединяющим фактором для группы выступает способ жизнеобеспечения (попрошайничество). Обобщенные характеристики дополняют отдельные жизненные истории - частные случаи из тысяч судеб людей, оказавшихся на «краю» или на самом «дне» жизни.

Основным источником послужат материалы статистического учета и документы, собранные Комитетом государственного контроля СССР в 1954 г. в ходе проверки состояния борьбы с нищенством и бродяжничеством. Специальные инспекторские группы в течение 20 дней работали в союзных и автономных республиках, областях и крупных городах страны. Объектами проверки стали органы социального обеспечения, однако контролеры министерства получали также информацию от муниципальных органов (исполкомов), милиции - главное - из «первых рук», т.е. беседуя непосредственно с людьми, занимающимися нищенством. 


\section{Статистика нищенства}

До середины 1950-х гг. в Советском Союзе не было централизованного учета граждан, занимающихся попрошайничеством, отсутствовали данные о масштабах распространения этого явления и составе нищенствующей публики. Последние статистические сведения о нищенстве в СССР были получены на основе переписи 1926 г., а после этого учет нищих проводился в порядке рутинного надзора милицейских органов за соблюдением паспортного режима или в результате специальных акций по борьбе с нищенством.

В 1954 г. появились первые обобщающие учетные данные о количестве нищих в СССР. Учетом занимались территориальные органы милиции, которые по специальной форме должны были предоставлять в Министерство внутренних дел СССР сведения о количестве нищенствующих, их категориях (инвалидах, престарелых гражданах, женщинах с детьми, профессиональных нищих), наличии или отсутствии пенсии, длительности занятия нищенством. Поскольку данные на нищих собирали территориальные органы милиции, они включали в сводки только лиц, имеющих постоянное место жительства. Нищие, не имеющие постоянной прописки, не учитывались, хотя бездомные составляли одну из основных групп риска среди побирающейся публики. Кроме того, вне учета оказались люди, занимающиеся попрошайничеством и находящиеся на «государственном обеспечении» в домах инвалидов и домах престарелых. В сводках отсутствуют обобщающие сведения о возрасте и поле задержанных за нищенство, хотя такие данные есть по отдельным городам и регионам.

Сама процедура учета не была отлажена в полной мере, поэтому данные постоянно уточнялись. Так, на 1 августа 1954 г. по сведениям милицейской статистики - 20509 нищих в целом по СССР, а через два месяца эта цифра выросла до 21790 (ГАРФ. Ф. Р-9415. Оп. 3. Д. 256. Л. 57-58). Проверка состояния борьбы с нищенством 1954 г. зафиксировала распространение обоих типов нищенства - профессионального и вынужденного (Таблица 1). При этом критерии выделения «профессионалов» в отдельную категорию оставались неясными. Помимо них органы милиции отдельно фиксировали людей, которые занимались нищенством «постоянно». Поскольку в категорию профессиональных нищих не включались инвалиды, старики и женщины с детьми, можно предположить, что «профессионалами» считались исключительно трудоспособные мошенники, т.е. люди, не нуждающиеся в социальной поддержке. Таких среди зарегистрированных органами милиции нищих было всего 6,4\%. При этом доля тех, кто занимался нищенством постоянно, составила $39 \%$. Эта группа состояла из инвалидов, женщин с малолетними детьми и стариков. Факт постоянного попрошайничества означал, что этот вид «заработка» был для них если не единственным, то одним из главных способов жизнеобеспечения. Таким образом, среди учтенных нищих почти половина, 45 \%, если пользоваться лексикой милицейских документов, «сделали нищенство своей профессией». 
Сведения о лицах, занимающихся нищенством (по состоянию на 25 сентября 1954 г.).

\begin{tabular}{|c|c|c|c|c|}
\hline Категории нищих & 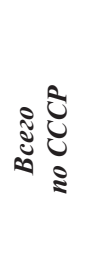 & 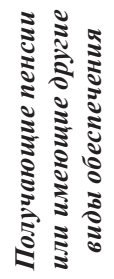 & 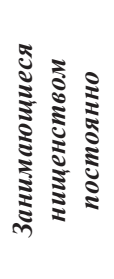 & 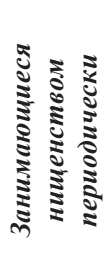 \\
\hline Инвалиды войны & 2941 & 2306 & 1205 & 1736 \\
\hline Инвалиды труда & 3186 & 1935 & 1364 & 1822 \\
\hline Инвалиды случая & 1786 & 466 & 884 & 902 \\
\hline Инвалиды с детства & 2262 & 541 & 1026 & 1236 \\
\hline Престарелые & 7983 & 2500 & 3599 & 4384 \\
\hline Женщины с детьми & 916 & 266 & 424 & 492 \\
\hline Профессиональные нищие & 1402 & - & - & - \\
\hline Прочие & 1314 & - & - & - \\
\hline ИТОГО & 21790 & 8014 & 8502 & 10572 \\
\hline
\end{tabular}

Источник: Сведения о количестве лиц, занимающихся нищенством по СССР (по состоянию на 25 сентября 1954 г.) ГАРФ. Ф. 9415. Оп. 3. Д. 256. Л. 57-58

\section{Факторы риска нищенства в контексте советской системы социального обеспечения}

Наличие широкого слоя социально незащищенных людей, для которых выпрашивание милостыни стало единственным способом выживания, само по себе было тревожным сигналом. Как свидетельствовали документы, причины, толкающие людей на путь нищенства, были разными: низкий уровень доходов в виде пенсии или зарплаты (прежде всего, отсутствие пенсии или ее маленький размер), отсутствие постоянного места жительства, преклонный возраст, инвалидность, болезнь (в том числе алкоголизм), сиротство, многодетность, невозможность найти работу, одиночество, наличие судимости, утрата документов.

Важную роль играл социальный статус: для человека с пониженным социальным статусом - например, для осужденных, амнистированных возвращение к «нормальной» жизни связано с дополнительными сложностями. Иными словами, для человека, однажды исключенного из социума, возможности «обратного включения» ограничены. Инерция исключения 
продолжала действовать и после того, как был формально снят статус исключенного (например, при освобождении и снятии судимости).

Часто к нищенству вела совокупность факторов риска: старость была связана с болезнями, инвалидностью и одиночеством; среди многодетных матерей или бывших воспитанников детских домов (сирот) встречались люди с криминальным прошлым; инвалиды одновременно могли быть безработными или имели судимость; алкоголизмом страдали инвалиды, престарелые и вернувшиеся из заключения. Как показали результаты проверки 1954 г., одной из основных причин, ведущих к нищенству, были недостатки советской пенсионной системы - маленький размер пенсии или ее отсутствие (ГАРФ. Ф. Р-8300. Оп. 2а. Д. 93. Л. 186-187). Среди нищих, включенных в статистику 1954 г., только $37 \%$ получали пенсии и другие виды социальных пособий. Даже среди нищенствующих инвалидов лишь чуть более половины (52\%) имели пенсии, среди такой категории, как инвалиды с детства,- только $24 \%$. Доля получающих пенсии стариков, занимающихся нищенством, составляла 31 \% (ГАРФ. Ф. Р-9415. Оп. 3. Д. 256. Л. 57-58).

Причем и эти данные неадекватно отражали реальную картину: факт наличия пенсии не гарантировал социальную защищенность. Большинство людей, вынужденных нищенствовать, если и получали пенсии, то очень маленькие, далеко не обеспечивающие прожиточный минимум. До 1956 г. минимальный размер пенсии в СССР составлял 14 руб. 90 коп. для жителей сельской местности и 74 руб. 90 коп. в городе (с учетом «хлебной надбавки», введенной в 1946 г.). Для сравнения: пенсионной реформой 1956 г. минимальный размер пенсии по старости был определен в размере 300 руб. Доходы от нищенства не шли ни в какое сравнение с размерами социального обеспечения. По показаниям нищих, их дневной «заработок» в зависимости от места и сезона - колебался от 15 до 30 руб. по будням и доходил до 40-70 руб. в воскресные и праздничные дни.

Советская пенсионная система до реформы 1956 г. была выстроена таким образом, что от социальной поддержки отсекались целые группы нуждающихся в ней людей или эта возможность минимизировалась (Mücke 2013; Физелер 2005). Для того, чтобы получать пенсию, необходимо было иметь трудовой стаж не менее одного года. Таким образом, права на пенсию лишались инвалиды с детства (они могли получать пенсию, например, за умерших родителей, но не на основании собственного увечья или болезни). После войны в таком же дискриминационном положении оказались молодые инвалиды-фронтовики, которые ушли на войну со школьной скамьи, не успев заработать свой «трудовой стаж». Для оформления пенсии требовались документы, подтверждающие трудовой стаж, однако у многих за время войны эти документы были утрачены - сгорели или потерялись. На восстановление документов уходили месяцы, иногда - годы. Послевоенное нищенство - прямое следствие советской пенсионной системы, 
за рамками которой находились социально незащищенные группы населения.

Государственная стратегия адаптации инвалидов предлагала только один путь - трудоустройство. Принципу трудоустройства была подчинена и практика признания инвалидности: в первую очередь оценивалось не состояние здоровья, а степень трудоспособности. Было установлено три группы инвалидности: к инвалидам первой группы относились люди, «нетрудоспособные и требующие ухода»; вторая группа определялась для инвалидов, «нетрудоспособных, но не требующих за собой ухода»; третья группа давалась инвалидам, «ограниченно трудоспособным». Инвалиды третьей группы, несмотря на официальный статус «ограниченно трудоспособных», объявлялись «трудообязанными» (Физелер 2005). Органы социального обеспечения должны были заниматься трудоустройством инвалидов. Система специализированных предприятий для использования труда инвалидов и их переобучения существовала, но работала неэффективно. Плохие бытовые и производственные условия, частые простои, низкие заработки в инвалидных артелях делали их малопривлекательными для людей с ограниченными возможностями (ГАРФ. Ф. Р-8300. Оп. 2а. Д.93. Л. 181-184).

Для военных инвалидов с тяжелыми увечьями возможности адаптации к мирной жизни были совсем невелики: как правило, они нуждались в специальном уходе, который могли обеспечить либо семья, либо государство. Если не находились родственники, берущие инвалидов под опеку, то единственным прибежищем для них оставался дом инвалидов. Дома инвалидов и престарелых - еще одно уязвимое звено советской системы социального обеспечения. Нищие делились на две категории: одни просили поместить их в дома инвалидов, но не могли туда попасть, другие имели на это право, но категорически отказывались жить в доме инвалидов. В дома инвалидов и престарелых не принимали граждан, имеющих родственников, лиц без регистрации, колхозников, людей из других городов и районов. Кроме того, отказывали в приеме старикам и инвалидам без документов - а таких среди нищих было большинство.

У тех нищих, кто отказывался от направления в дома инвалидов или бежал оттуда при первой возможности, были свои аргументы. Главный из них - состояние домов инвалидов и престарелых. Условия жизни в этих домах включали скудный рацион, скученность (по 20-50 человек в одной палате), нехватку одежды и обуви, отсутствие врачей и лекарств, изолированность от внешнего мира. Случалось, что и обитатели инвалидных домов занимались нищенством (ГАРФ. Ф. Р-8300. Оп. 2а. Д. 93. Л. 142). Иногда нищие сами просились в дома инвалидов осенью, а с наступлением весны снова уходили на свой промысел. Нищенство для этой категории людей стало уже образом жизни. Поэтому многие не желали от него отказываться, считая этот образ жизни «спокойным и ни от кого не зависимым» (ГАРФ. Ф. Р-8300. Оп. 2а. Д. 93. Л. 158). 


\section{Социальное лицо нищенства}

Среди занимающихся нищенством, можно выделить несколько социальных типажей, которые фигурировали в документах: инвалиды (всех возрастов и категорий), старики, одинокие матери с детьми, многодетные родители, люди с судимостью, выпускники детских домов, бывшая домашняя прислуга, больные алкоголизмом. Подобная дифференциация помогает представить социальное лицо нищенства, хотя она довольно условная, поскольку обозначенные типажи, как и факторы риска, часто носили смешанный характер. Типичный персонаж, просящий подаяние,- одинокий престарелый инвалид. Инвалиды и старики представляли собой самую многочисленную группу среди нищих - 83,3\%, по данным учета 1954 г.

Инвалиды. Согласно милицейской статистике, почти половина нищих (46,7\%) являлась инвалидами разных категорий, при этом на долю инвалидов войны приходилось 13,5\% нищенствующей публики (ГАРФ. Ф. Р-9415. Оп. 3. Д. 256. Л. 57). За годы, прошедшие после войны, многие военные инвалиды ушли из жизни, фронтовая компонента в составе постепенно становилась менее заметной. Но именно присутствие «на паперти» бывших фронтовиков тревожило современников, рождая недоумение, сочувствие, возмущение и вопросы (Dale 2015; Физелер 2005). Главный из них: как случилось, что многие фронтовики-победители, одолевшие войну, были повержены послевоенной повседневностью и так и не смогли найти достойного места в мирной жизни, пополняя ряды нищей братии?

Большинство нищенствующих инвалидов войны, включенных в статистику 1954 г., получали пенсии (78\%), но несмотря на это, 41 \% занимались попрошайничеством постоянно. Тому несколько причин, но чаще две: либо размер пенсии был недостаточен, чтобы содержать себя и семью, либо «на паперть» толкала болезнь, с фронтовым увечьем напрямую не связанная, алкоголизм:

Москвич, инвалид Отечественной войны І группы, лишился левой руки, пальцев правой руки и глаза, уже после демобилизации трамваем ему отрезало обе ноги. Получал пенсию 560 руб., но при этом систематически занимался нищенством с 1945 г. Как следует из медицинских документов, страдал психическим заболеванием на почве алкоголизма (ГАРФ. Ф. Р-8300. Оп. 2а. Д. 93. Л. 155).

Возможности дополнительного легального заработка для инвалидов, особенно с тяжелыми увечьями, например, для людей, лишившихся зрения, были серьезно ограничены:

В подмосковных поездах часто можно было видеть слепого инвалида с баяном. Он получал пенсию как инвалид Отечественной войны I группы, но при этом приходилось содержать большую семью - пятерых детей от первого и второго браков. В пьянстве замечен не был - нечастый случай среди вагонных и трамвайных «музыкантов». Райсобес предложил ему устроиться на работу в артель инвалидов с заработком в 700 руб. в месяц, 
но получил категорический отказ. Игра на баяне приносила гораздо более существенный доход - до 3000 руб. в месяц. Кроме того, сам инвалид не считал, что занимается нищенством (ГАРФ. Ф. Р-8300. Оп. 2а. Д. 93. Л. 154).

Одной из самых социально незащищенных групп населения являлись инвалиды с детства, большинство из которых по причине отсутствия «трудового стажа» не имели права на пенсию ${ }^{1}$. Среди нищих, включенных в статистику 1954 г., каждый десятый был инвалидом с детства. Для детей-инвалидов возможности восходящей социальной мобильности в отличие от здоровых сверстников сведены к минимуму, и многие из них были обречены оставаться в аутсайдерах. Заниженные стартовые возможности определяли последующую нисходящую жизненную траекторию:

В свои 23 года он уже имел устойчивую репутацию «пьяницы и хулигана». Инвалидность получил в детстве - в результате несчастного случая лишился обеих ног. Стал занимался нищенством и воровством. Потом женился, появились двое детей. Пошел работать в инвалидную артель, но оттуда его уволили за кражу и постоянное пьянство. Жена от него ушла. Без пенсии и без работы зарабатывал на жизнь нищенством (ГАРФ. Ф. Р-8300. Оп. 2. Д. 1399. Л. 46-47).

Как правило, милицейские справки скупы на подробности, но за этими, казалось бы, сугубо «информационными» сведениями скрываются драматичные жизненные истории: «П., 1905 г.р., слепая с детства, нищенствует с 1925 года по разным городам страны. К., 1914 г.р., слепая, нищенствует с 1950 г. И., 1933 г.р., слепой, нищенствует систематически. ..» (ГАРФ. Ф. Р-8300. Оп. 2. Д. 1401. Л. 41-42).

Старики. После инвалидов самой многочисленной группой среди лиц, занимающихся нищенством, были престарелые граждане - 36,6\% в 1954 г. В большинстве - одинокие, больные люди, не имеющие материальной поддержки в виде пенсии или помощи родственников, иногда не имеющие даже дома:

В Ростове неоднократно задерживался за нищенство 90-летний старик. Из документов известно о нем немного: «Пенсии не получает, не имеет родственников, нет определенного места жительства. Начал нищенствовать в 1933 году и с тех пор путешествует по городам нашей страны. Просится в дом престарелых, но его нигде не принимают» (ГАРФ. Ф. Р-8300. Оп. 2. Д. 1401. Л. 41).

В бедственном положении могли оказаться престарелые одинокие колхозники. Возможности социальной поддержки для них были значительно хуже, чем для городских жителей или для работающих на государственных предприятиях: помощь родных, пенсия (за умерших родственников, если они служили в армии), пособие от колхоза или колхозный дом престарелых. Но у колхозов просто не хватало средств на выделение пособий и содержание

\footnotetext{
${ }^{1}$ Инвалиды с детства получили право на пенсию только в 1967 г.
} 
своих домов инвалидов и престарелых (последние финансировались из касс взаимопомощи колхозников). В РСФСР - все еще преимущественно «сельской» по составу населения - на начало 1954 г. действовало всего 70 колхозных домов для престарелых, и их было почти в шесть раз меньше, чем государственных домов инвалидов и престарелых, - 410 (ГАРФ. Ф. Р-8300. Оп. 2а. Д. 93. Л. 178, 180). Оставшиеся без средств существования колхозные старики отправлялись в города просить милостыню:

В Ленинграде за нищенство была задержана пожилая женщина 65 лет. Она пришла из Псковской области, где до недавнего времени работала в колхозе. Ее муж во время войны был партизаном, погиб в 1942 г. В милиции она рассказала: «Причиной к нищенству послужило то, что я осталась одна - года́ вышли, чтобы работать в колхозе, а дети от меня отказались». Попытки женщины получить пенсию или пособие оказались безрезультатными (ГАРФ. Ф. Р-8300. Оп. 2. Д. 1397. Л. 49-50).

Жизненные истории этих людей показывают, почему нищенский промысел стал для них единственно возможным способом выживания: виной тому были отсутствие пенсии и невозможность получить место в доме престарелых.

Воспитанники детских домов. Среди нищих была заметна прослойка людей с сиротским и детдомовским прошлым. Их истории похожи: после детдома - ремесленное училище, там они обучались рабочей профессии не по собственному выбору и часто связанной с тяжелыми условиями труда. Побеги из ремесленных училищ были обычной практикой. После окончания обучения 15-16-летние подростки не всегда приживались на рабочем месте, тоже уходили «в бега». Лишившись работы, без поддержки родственников начинали бродяжничать и нищенствовать:

За бродяжничество и нищенство сразу в нескольких городах на юге России неоднократно задерживалась молодая женщина. Как круглая сирота, она воспитывалась в детском доме. В 14 лет из детского дома была направлена в ремесленное училище и получила там совсем не «женскую» профессию кочегара. Почти три года девушка-кочегар проработала на разных теплоходах, но в 1947 г. была осуждена за кражу 20 литров спирта. В 1953 г. ее освободили по амнистии и направили на постоянное место жительство в Удмуртскую АССР. Выдали паспорт. Однако работу она найти так и не смогла: амнистированных принимали неохотно. С этого момента началась ее бродяжья жизнь, средства к существованию пришлось добывать попрошайничеством, а потом нищенский промысел превратился в привычку (ГАРФ. Ф. Р-8300. Оп. 2а. Д. 98. Л. 132).

Женщина с ребенком. Это - традиционный типаж нищих. Как правило, это были матери-одиночки, но встречались и женщины, имеющие мужа (в этом случае нищенство часто являлось семейным промыслом). Причины, толкнувшие их «на паперть», могли быть разными. Чаще других упоминаются в документах невозможность устроиться на работу, судимость, отсутствие жилья, утрата документов: 
Она начала бродяжничать с 10-летнего возраста, никогда не имела ни своего жилья, ни постоянной работы. В 1945 г. была осуждена на пять лет тюремного заключения. После освобождения поехала в Ленинград к своей сестре, но сестра ее не приняла. Оставшись без дома, без работы, женщина начала нищенствовать. Потом родила ребенка и теперь собирала милостыню вместе с ним: «Я выпрашиваю с малолетним ребенком, притом всегда плачу, поэтому меня нигде не обижают». Нищенством женщина с ребенком зарабатывала 15-20 руб. в день (ГАРФ. Ф. Р-8300. Оп. 2. Д. 1397. Л. 46).

Многие матери, выпрашивающие милостыню вместе с детьми, действительно имели проблемы с устройством на работу. Начальник одного из приемников-распределителей для нищих сравнивал ситуацию с трудоустройством одиноких матерей с «заколдованным кругом»: «С ребенком не берут на работу, пока его не устроишь в ясли, а в ясли не берут, пока не поступишь на работу, а на работу не оформляют до тех пор, пока не пропишешься...» (ГАРФ. Ф. Р-8300. Оп. 2. Д. 1397. Л. 146).

Дети. После всплеска детского нищенства в военные и послевоенные годы количество нищенствующих детей с конца 1940-х гг. стало сокращаться (Зубкова 2016; Зезина 1999). В 1950-е гг. фиксировались только отдельные случаи детского нищенства как самостоятельного явления. Например, на Ленинградском узле Октябрьской железной дороги с января по сентябрь 1954 г. было задержано за нищенство 1120 человек, из них семь детей, без учета детей, которые занимались попрошайничеством вместе со взрослыми (ГАРФ. Ф. Р-8300. Оп. 2. Д. 1397. Л. 82). Как правило, такие дети либо жили в проблемных семьях, либо страдали психическим заболеванием (ГАРФ. Ф. Р-8300. Оп. 2. Д. 1400. Л. 29-30). Систематическое занятие попрошайничеством превращалось в привычку. Не менее опасным для вовлечения в нищенство детей был пример взрослых, когда ребенок попадал в неблагоприятную социальную среду:

После смерти родителей 10 -летняя Нина переехала жить к своей тете в Новосибирск. Вскоре девочка была задержана сотрудниками милиции в городском парке, где она просила милостыню. Оказалось, что этим промыслом занимаются многие жильцы барака-общежития, куда попала Нина. Большинство обитателей барака работали в артели Всероссийского общества слепых, и свое поведение они объясняли следующим образом: когда в артели случались перебои с поставкой сырья, и зарплата не выплачивалась, приходилось нищенствовать (ГАРФ. Ф. Р-8300. Оп. 2. Д. 1400. Л. 31).

Люди, зависимые от алкоголя. Алкоголизм как провоцирующий нищенство фактор присутствует во многих документах. В справке, подготовленной по итогам проверки борьбы с нищенством в Москве, приводятся 27 персональных примеров, 15 из которых так или иначе были связаны с пристрастием к алкоголю (ГАРФ. Ф. Р-8300. Оп. 2а. Д. 93. Л. 152-167). На почве алкоголизма к попрошайничеству прибегали люди, имеющие работу и приличную зарплату, хорошую пенсию, члены КПСС. Алкоголизм как фактор риска вел не только к нищенству - сам факт занятия этим промыслом сви- 
детельствовал о процессе социальной дезадаптации, социальной эксклюзии. В документах партийных и правоохранительных органов такие люди обычно проходили по категории «морально разложившихся»:

С 1952 г. нищенствует Л., 1893 г.р., с высшим образованием, имеет дочь (врача) и других родственников, которые от него отказываются, так как он постоянно пьянствует. Ночует в развалинах, в садах, в парках города. Д., 1893 г.р., бывший судейский работник, проработавший в органах юстиции 16 лет. Постоянно пьянствует, добывая для этого средства путем нищенства. Пьянствуют и нищенствуют ряд инвалидов Отечественной войны. Неоднократно задерживали за нищенство спившегося майора в отставке Л., получающего пенсию 910 руб. (ГАРФ. Ф. Р-8300. Оп. 2. Д. 1401. Л. 41).

Профессиональные нищие. Коллективный портрет советского нищего 1950-х гг. будет неполным без его профессиональной компоненты. Провести четкую границу, отделяющую вынужденное нищенство от профессионального, довольно сложно. Иногда достаточно было решить вопрос с пенсией, и человек прекращал заниматься попрошайничеством. Но чаще длительная привычка к нищенству закреплялась в виде устойчивого образа жизни, а попрошайничество становилось главным способом жизнеобеспечения, т.е. своего рода «профессией», которая требовала сил, специальных навыков и приносила весомый доход. Поэтому было бы не вполне корректным относить все случаи постоянного нищенства к его профессиональной разновидности: люди, находящиеся за чертой бедности, не имеющие возможности выбраться из нищеты, а также зависимые от алкоголя, выпрашивающие копейки на выпивку, не являлись в строгом смысле слова профессиональными нищими.

При задержании у профессиональных нищих нередко оказывались при себе большие суммы денег. Так, в Ленинграде у одной нищенки сотрудники милиции обнаружили 9944 руб., зашитыми в подоле платья, у другой 350 руб. и сберкнижку с вкладом на сумму 1570 руб., а у их «коллеги» нашли две сберкнижки с общим вкладом на сумму 2500 руб. (ГАРФ. Ф. Р-8300. Оп. 2. Д. 1397. Л. 4).

Помимо финансовых причин распространение профессионального нищенства было связано с влиянием культурной традиции, когда нищенское ремесло передавалось «по наследству». Среди нищих-профессионалов встречались одиночки, но чаще они объединялись в сообщества, «нищенские гнезда». «Нищенские гнезда» как форма самоорганизации профессиональных нищих сохранились еще с дореволюционных времен. Это были деревни, жители которых, как правило, целыми семьями практиковали нищенство в качестве своего рода отхожего промысла. В РСФСР по степени распространенности «нищенских гнезд» уверенно лидировала Калужская область (Кометчиков 2014). В 1954 г. на учете Управления милиции УМВД Калужской области состояло 1114 местных жителей, занимающихся нищенством, в том числе 46 инвалидов войны, 53 инвалида труда, 80 прочих инвалидов, 213 престарелых и 579 трудоспособных (ГАРФ. Ф. Р-8300. Оп. 2а. Д. 93. Л. 22). 
Таким образом, половина профессиональных нищих были людьми трудоспособными. О «нищенских гнездах» в Калужской губернии писал Август Левенстим, выделяя несколько сел: Большие и Малые Желтоухи, Воткино, Барсуки (Левенстим 2004: 57). Уже в советское время там возникли колхозы, и, как когда-то крестьяне этих деревень, теперь в милицейские сводки то и дело попадали колхозники, задержанные за нищенство, из хозяйств им. Кутузова, им. 19 партсъезда, им. Ворошилова, «Рассвет»:

В трудоспособной семье Е., состоящей из жены 51 года, двоих сыновей Михаила 15 лет и Сергея 24 лет, и двоих дочерей 19 и 25 лет, постоянно занимаются нищенством жена, дочери и сын Михаил, которые с этой целью выезжали из дома, в текущем году от 2 до 4 раз и задерживались органами милиции г. Москвы. В хозяйстве имеется дом, приусадебный участок 0,26 га, корова, телка, свинья, 5 семей пчел, велосипед, швейная машина (ГАРФ. Ф. Р-8300. Оп. 2а. Д. 93. Л. 24-25).

В существующих под видом колхозов «нищенских гнездах» этим промыслом занимался колхозный актив, члены партии и комсомольцы - вместе с семьями, взрослыми и детьми. В «сезон», совпадающий с началом учебного года, дети не посещали школу, многие сидели по несколько лет в одном классе. Нищенский промысел был хорошо организован: новички проходили «производственное обучение», руководство колхозов выдавало фальшивые справки-разрешения на выезд, в городах имелись связи с людьми, предоставляющими временное жилье, при выпрашивании милостыни использовались соответствующая профессиональная экипировка и легенда. Все попытки ликвидировать нищенство в колхозах Калужской области - от административно-репрессивных до экономических - положительного результата не имели: инерция традиции и экономическая выгода были сильнее угроз и убеждений (ГАРФ. Ф. Р-8300. Оп. 2а. Д. 98. Л. 91).

\section{Заключение}

Реконструкция коллективного портрета советского нищего 1950-х гг. показывает, что нищенство как социальное явление было многолико: среди нищих - люди разных возрастов, мужчины и женщины, жители города и села, инвалиды и трудоспособные. По мотивации нищенство в СССР, как и в дореволюционный период, можно разделить на вынужденное и профессиональное. Вместе с тем профессионалы-мошенники, хотя и продолжали сохранять свои позиции в качестве наиболее устойчивой и сплоченной группы в составе нищенствующей публики, по численности уступали «вынужденным» нищим. Советские нищие в основном рекрутировались из социально незащищенных и уязвимых слоев населения - инвалидов, стариков, одиноких матерей, бездомных, людей с судимостью. В числе главных факторов риска, толкающих людей «на паперть», были крайняя бедность, отсутствие пенсии и другой социальной поддержки, невозможность найти работу, утрата документов, 
болезнь. «Случайное» нищенство запускало механизм социальной эксклюзии, когда вынужденный промысел, обретая силу привычки, превращался в постоянный. Следующей ступенью жизненной траектории были либо полная депривация, либо переход в категорию профессиональных нищих.

Наличие значительного числа людей, занимающихся нищенством постоянно, а также широкого спектра факторов риска, связанных с нищенством, свидетельствовало о серьезных изъянах советской социальной политики, особенно в части поддержки незащищенных слоев населения и разработки адаптационных стратегий для аутсайдеров. Ситуация начала меняться в середине 1950-х гг., когда борьба с бедностью стала одним из приоритетов социальной политики.

\section{Список сокращений}

ГАРФ - Государственный архив Российской Федерации

\section{Список архивных источников}

Государственный архив Российской Федерации. Ф. Р-8300. Оп. 2. Д. 1397. Л. 4, 46,49-5082, 146; Д. 1399. Л. 46-47; Д. 1400. Л. 29-31. Д. 1401. Л. 41-42.

Государственный архив Российской Федерации.Ф. Р-8300. Оп. 2а. Д. 93. Л. 22, 142,152-167, 181-187; Д. 98. Л. 91, 132

Государственный архив Российской Федерации.Ф. Р-9415. Оп. 3. Д. 256. Л. 57-58

\section{Список источников}

Бутовская М. Л., Дьяконов И. Ю., Ванчатова М.А. (2007) Бредущие среди нас. Нищие в России и странах Европы, история и современность. М.: Научный мир.

Герцензон А.А. (1995) Нищенство и борьба с ним в условиях переходного периода (1929 г.). М.В. Фирсов (ред.) Антология сочиальной работы, T. 2. М.: Сварогъ - НВФ СПТ: 68-89.

Дьяконов И.Ю. (2007) Нищенство в дореволюционной России. Этнографическое обозрение, (3): $26-38$.

Зезина М.Р. (1999) Социальная защита детей-сирот в послевоенные годы (1945-1955). Вопросы истории, (1): 127-136.

Зубкова Е.Ю. (2016) Дети войны: положение и стратегии выживания беспризорных и безнадзорных детей в СССР. 1942-1948 гг. Российская история, (4): 52-65.

Левенстим А. А. (2004) Профессиональное нищенство. Его причины и формы. В.П. Миловидов (ред.) Нищенство. Ретроспектива проблемы. СПб.: Крига: 18-92.

Ильясов Ф.Н., Плотникова О.А. (1994) Нищие в Москве летом 1993 года. Соииологический журнал, (1): 150-156.

Кометчиков И.В. (2014) Традиция якутальства как грань «социального иммунитета» Калужской деревни и борьба с ней в 1930-е-начале 1960-х гг. Антропологический форум, (20): 240-340.

Физелер Б. (2005) «Нищие победители»: инвалиды Великой Отечественной войны в Советском Союзе. Неприкосновенный запас, 40/41 (2-3): 290-297.

Althammer B. (ed.) (2007) Bettler in der europäischen Stadt der Moderne. Zwischen Barmherzigkeit, Repression und Sozialreform. Frankfurt am Main: Peter Lang.

Dale R. (2015) Demobilized Veterans in Late Stalinist Leningrad. Soldiers to Civilians. London: Bloomsbury Academic.

Mücke L. (2013) Die allgemeine Altersrentenversorgung in der UdSSR, 1956-1972. Stuttgart: Franz Steiner Verlag.

Fieseler B. (2006) The Bitter Legacy of the 'Great Patriotic War': Red Army Disabled Soldiers under Late Stalinism. J. Fürst (ed.) Late Stalinist Russia. Society between Reconstruction and Reinvention. New York: Routledge: 46-61.

Zubkova E. (2013) Les exclus. Le phénomène de la mendicité dans l'Union soviétique d'aprèsguerre Annales. Histoire, Sciences Sociales, 2 (68): 357-388. 


\section{THE 'SOVIET BEGGAR': RECONSTRUCTION OF THE COLLECTIVE PORTRAIT OF BEGGARS IN 1950 S}

The article reconstructs the collective portrait of the Soviet beggars in the mid-1950s, the complex of demographic, economic, sociocultural characteristics presenting beggars as a marginal social group. The study is based on the statistical data of the Ministry of Internal Affairs and the documents of the State Control Committee, which organized the inspection of the state of begging in different towns and regions of the USSR in 1954. These sources contain information on the number of beggars, age, living standard, motivations for the begging. The motives (risk factors) that led individuals to begging were different: poverty, lack of social support, old age, disability, illness (including alcoholism), homelessness, large families, inability to find work, loneliness, criminal backgrounds, loss of documents, etc. As a rule, a set of risk factors led to begging. Among those involved in begging, there were several social types: disabled people, elderly people, single mothers with children, parents with many children, people with a criminal record, orphans, former domestic servants and alcoholics. These types, like risk factors, often had a mixed character. 'Professional' beggars occupied their own 'social niche', although the number of 'professional' beggars was significantly less than the 'forced' ones. The presence of a significant number of people practicing begging as the main survival strategy in the Soviet society, as well as a wide range of risk factors provoking begging, testified to the serious defects of the Soviet social policy, especially concerning support of socially vulnerable groups and the development of adaptation strategies for outsiders.

Keywords: begging, poverty, social policy, exclusion, marginality

DOI: 10.17323/727-0634-2018-16-2-221-236

\section{References}

Althammer B. (ed.) (2007) Bettler in der europäischen Stadt der Moderne. Zwischen Barmherzigkeit, Repression und Sozialreform. Frankfurt am Main: Peter Lang.

Butovskaja M.L., D‘jakonov I. Ju., Vanchatova M. A. (2007) Bredushhie sredi nas. Nishhie v Rossii i stranah Evropy, istorija i sovremennost' [Ranchers among Us. Beggars in Russia and Europe, History and Modernity]. Moscow: Nauchnyj mir.

Dale R. (2015) Demobilized Veterans in Late Stalinist Leningrad. Soldiers to Civilians. London: Bloomsbury Academic.

Elena Zubkova - Doctor of History, Chief Research Fellow, Head of the Center for Social History of Russia, Institute of Russian History of the Russian Academy of Sciences, Moscow, Russian Federation. Email: elena.zubkova@mail.ru 
D’jakonov I. Ju. (2007) Nishhenstvo v dorevoljucionnoj Rossii [Begging in Pre-revolutionary Russia]. Etnograficheskoe obozrenie [Ethnographic Review], (3):26-38.

Fieseler B. (2005) 'Nishhie pobediteli': invalidy Velikoj Otechestvennoj vojny v Sovetskom Sojuze ['Beggar Winners': Disabled Veterans of the Great Patriotic War in the Soviet Union]. Neprikosnovennyj zapas, 40/41 (2-3):290-297.

Fieseler B. (2006) The Bitter Legacy of the 'Great Patriotic War': Red Army Disabled Soldiers under Late Stalinism. Fürst J. (ed.). Late Stalinist Russia. Society between Reconstruction and Reinvention. New York: Routledge:46-61.

Gercenzon A. A. (1995) Nishhenstvo i bor'ba s nim v uslovijah perehodnogo perioda (1929) [Begging and the Fight Against it in the Transition Period]. M. V. Firsov (ed.) Antologija social'noj raboty [Anthology of Social Work], Vol. 2. Moscow: Svarog - NVF SPT: 68-89.

Il'yasov F.N., Plotnikova O.A. (1994) Nishchie v Moskve letom 1993 goda. [Beggars in Moscow the Summer of 1993]. Sociologicheskij zhurnal [Sociological Journal], (1): 150-156.

Kometchikov I. V. (2014) Tradicija jakutal'stva kak gran' 'social'nogo immuniteta' Kaluzhskoj derevni i bor'ba s nej v 1930-e-nachale 1960-h gg. [Begging Traditions a Facet of the 'social immunity' of the Kaluga village and its struggle in the 1930s and early 1960s]. Antropologicheskij forum [Anthropological Forum], (20): 240-340.

Levenstim A. A. (2004) Professional'noe nishhenstvo. Ego prichiny i formy [Professional Begging. Its Causes and Forms]. V.P. Milovidov (ed.). Nishhenstvo. Retrospektiva problem [Begging. Retrospective of the Problem]. St. Petersburg: Kriga: 18-92.

Mücke L. (2013) Die allgemeine Altersrentenversorgung in der UdSSR, 1956-1972. Stuttgart: Franz Steiner Verlag.

Zezina M.R. (1999) Social'naja zashhita detej-sirot v poslevoennye gody (1945-1955) [Social Protection of Orphans in the Post-war Years (1945-1955)]. Voprosy istorii [Issues of History], (1): 127-136.

Zubkova E. (2013) Les exclus. Le phénomène de la mendicité dans l'Union soviétique d'aprèsguerre. Annales. Histoire, Sciences Sociales, 2 (68):357-388.

Zubkova E. Ju. (1016) Deti vojny: polozhenie i strategii vyzhivanija besprizornyh i beznadzornyh detej v SSSR. 1942-1948 gg. [Children of War: The Situation and Survival Strategies for Homeless and Neglected Children in the USSR, 1942-1948]. Rossijskaja istorija [Russian History], (4): 52-65. 